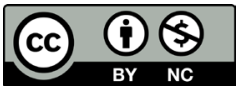

Licenciado sob uma licença Creative Commons

ISSN 2175-6058

DOI: http://dx.doi.org/10.18759/rdgf.v20i3.1767

\title{
CONSTITUCIONALISMO DE FICÇÕES: RESSENTIMENTO E ROMANCES DE FORMAÇÃO DO BRASIL
}

\section{FICTION CONSTITUTIONALISM: RESENTMENT AND BRAZIL'S NOVELS OF FORMATION}

Andre Karam Trindade

Guilherme Gonçalves Alcântara

\section{RESUMO}

Trata-se de artigo circunscrito às pesquisas em Direito e Literatura, especificamente Direito através da Literatura, que expõe, mediante um passeio panorâmico por diversos textos literários, o potencial das ficções para o estudo do constitucionalismo brasileiro. A premissa adotada é de que certas ficções, sobretudo as que tematizam o ressentimento, permitem acessar o contexto histórico, social e cultural em que vigoraram as constituições brasileiras ao longo da história. Conclui que, na companhia de Machado de Assis, Graciliano Ramos e Guimarães Rosa, é possível não somente compreender o passado, mas também antecipar momentos em que a cultura jurídica nacional cederia a processos de retrocesso na separação dos poderes e garantia dos direitos fundamentais.

Palavras-chave: Constitucionalismo. Literatura. Ressentimento.

\section{ABSTRACT}

This article is limited to research in Law and Literature, specifically Law through Literature, which exposes, through a panoramic tour through various 
literary texts, the potential of fictions for the study of Brazilian constitutionalism. The premise adopted is that certain fictions, especially those that address resentment, allow access to the historical, social and cultural context in which the Brazilian constitutions were enforced throughout history. It concludes that, in the company of Machado de Assis, Graciliano Ramos and Guimarães Rosa, it is possible not only to understand the past, but also to anticipate moments in which the national legal culture would yield to processes of regression in the separation of powers and guarantee of fundamental rights.

Keywords: Constitutionalism. Literature. Resentment.

\section{INTRODUÇÃO}

0 presente artigo é o resultado parcial de pesquisas desenvolvidas sobre "Constitucionalismo e Literatura", junto ao Programa de PósGraduação em Direito da UNIFG, no âmbito do SerTão - Núcleo Baiano de Direito e Literatura (DGP/CNPq). Seu objetivo reside em apresentar, mediante um passeio panorâmico sobre alguns textos literários, o poder das ficções para os estudos em Direito Constitucional, de modo a estabelecer aportes e caminhos para pesquisas em Direito $\mathrm{na}$ ou através da Literatura, sub-ramo desta articulação interdisciplinar que procura refletir sobre temas sensíveis dos juristas por meio de suas representações literárias ${ }^{1}$ (OST, 2004, p. 11, TRINDADE, BERNSTS, 2017).

Toma-se como questão-problema de pesquisa o fenômeno do ressentimento na Literatura e sua relação com uma concepção de justiça ancorada em princípios perenes e compartilhados, constitucionais. 0 ressentimento, como envenenamento psicofisiológico responsável pela deturpação da capacidade valorativa de seu portador, surge na prosa literária como sinais de decadência cultural catalisadora de profundos e violentos abalos nas instituições jurídico-políticas do "mundo real", sobretudo na força normativa das constituições. Trata-se, portanto, de um poderoso referencial teórico em pesquisas em Direito e Literatura, que será aplicado na pesquisa. 


\section{CONSTITUCIONALISMO, RESSENTIMENTO, E (IN)JUSTIÇA}

Engana-se quem pensa que o constitucionalismo é apenas um fenômeno jurídico-político, um conjunto de normas destinadas a limitar e dirigir as funções legislativa, judiciária e executiva dos Estados-nação modernos. 0 constitucionalismo é também um fenômeno históricocultural, ele existe na dimensão do imaginário social (VESPAZIANI, 2015, p. 81-82; BRUNER, 2014), conformando a compreensão-interpretaçãoaplicação do corpus juris (COVER, 2016). Estes pressupostos nos convocam a pensar o constitucionalismo cercado por outros fenômenos culturais, objetos de estudo das Humanidades (HABERLE, 2002). 0 viés cultural do constitucionalismo abre, assim, possibilidades de estudos interdisciplinares em Direito \& Literatura (LLANOS, 2017, p. 354).

As páginas dos grandes livros contam histórias sobre quem somos, e como nos tornamos quem somos, individual ou coletivamente. Alguns dos maiores ficcionistas nacionais viveram em períodos-chave da história política brasileira: Machado de Assis (1839-1908), na passagem do Império à República; Graciliano Ramos (1892-1953), preso, acusado de comunismo, às vésperas da implantação do Estado Novo; e Guimarães Rosa (1908-1967) publica sua obra-prima, Grande Sertão: Veredas, durante governo Kubitschek, no qual o Brasil evoluiria cinquenta anos em cinco. Todos eles participaram dos quadros do Estado, conheceram a realidade jurídico-política de seu país, e a representaram, intencionalmente, ou não, em suas ficções, deixando para nós, os leitores-juristas do presente, um poderoso e rico observatório/repositório cultural.

As ficções de Machado de Assis, Graciliano Ramos e Guimarães Rosa, contudo, não têm valor apenas para o exame do nosso passado. Estes escritores perceberam que estavam envoltos em uma atmosfera carente de valores perenes e positivos, em tempos de ressentimento para com o seu passado, sem perspectivas de futuro democrático e republicano. Eles anteviram períodos em que o processo de constitucionalização do Brasil se romperia e cederia espaço a modernizações autoritárias, sem qualquer respeito à separação de poderes e aos direitos fundamentais - princípios do constitucionalismo moderno. Eles serviram muitas vezes de oráculo 
para o que aconteceria em breve com as instituições jurídico-políticas de seu tempo.

Segundo um dos expoentes do Law \& Literature movement, Richard Weisberg (1984, p. 14), poucos temas da Literatura moderna são tão intrinsecamente relacionados ao Direito quanto o do ressentimento, revelado através do protagonista que se acredita peculiarmente ofendido por outras formas de vida, mais nobres, ao seu redor, verbalizando as mais excêntricas teorias para saciar sua sede de vingança. Pense em Hamlet, de Shakespeare, em Julien, de $O$ Vermelho e o Negro, de Stendhal, no protagonista de Notas do Subsolo, de Dostoievsky, ou no de Educação Sentimental, de Flaubert. Com credenciais intelectuais aparentemente impecáveis, estes personagens verborrágicos, letrados protagonistas, por vezes, juristas, se engajam em dotar a realidade de sentido narrativo, fracassando em tal empreitada. Quaisquer que sejam seus destinos, eles somente conseguem produzir destruição e morte, acobertadas por uma série de estruturas verbais enganosas.

0 ressentimento foi primeiramente trazido à reflexão filosófica por Nietzsche (1988) como o afeto dos fracos e incapazes de ação, que guiou a rebelião escrava na moral e determinou os valores cristãos e burgueses, consolidando a vitória sobre todos os valores positivos, ou constitucionais, em termos jurídicos, da Antiguidade. A crítica feroz de Nietzsche à rebelião escrava na moral se dirige aos primeiros cristãos, os quais rejeitaram toda a cultura greco-romana e pretenderam instaurar, com o Novo Testamento, seus valores reativos, nascidos do ressentimento do escravo contra o senhor. Mas a filosofia judaica e os aforismas de Nietzsche, na verdade, convergem ao apontar para poderosos e perenes conceitos éticos, bem como para uma noção de justiça como força ativa do indivíduo. Enquanto, porém, o judaísmo fundamenta sua ética em pressupostos metafísicos (Deus), Nietzsche a situa sob princípios históricos.

Para Nietzsche, a justiça é produto de valores comuns e perenes ${ }^{2}$, que bem poderiam ser consagrados em textos constitucionais. Ela é o oposto da sede de vingança que caracteriza a justiça privada do ressentido ${ }^{3}$, pois "o último terreno conquistado pelo espírito da justiça é o do sentimento reativo" (1988, p. 63). Trata-se de uma concepção de justiça ancorada em 
compromissos entre iguais que passam a reger a comunidade social, ou seja, em um sistema de leis cuja positividade constitui a ordem social e impede fazer valer exclusivamente a perspectiva do ofendido, forçando a composição, interditando o ato vingativo.

Justiça e ressentimento são, pois, em todos os sentidos, antagônicos. De tempos em tempos, as civilizações estabelecem um conjunto de princípios comuns que passam a reger a vida social: a aliança de Deus com Noé, a Lei das Doze Tábuas, a codificação napoleônica, e a promulgação da Constituição Federal Brasileira de 1988, são exemplos. Quando, porém, o ressentimento se alastra socialmente, sobretudo entre os juristas, estes princípios comuns são violados e cedem espaço a uma concepção parcial e desnecessariamente violenta de justiça, associada à reação a um trauma ou ofensa, real ou imaginada (FERRO, 2009). Nas palavras de Nietzsche (1988, p. 62), "sacraliza-se a vingança sob o nome de justiça". 0 ressentimento, "terreno dos afetos reativos, da vingança imaginária e adiada, da memória que só serve à manutenção de uma queixa repetitiva e estéril" (KEHL, 2015, p. 340), retira a autonomia do Direito reclamada pelo constitucionalismo, e o instrumentaliza para fins contingenciais e prosaicos. Quando surge nas ficções, entretanto, o ressentimento se torna um poderoso referencial teórico.

Como condição de rememoração permanente de um trauma, real ou imaginário, que impede a correta e efetiva compreensão do mundo ao redor de seu portador, o ressentimento tem na prosa realista a sua maior representatividade. Antes do filósofo alemão, os escritores do século XIX estavam colocando o ressentimento no centro de suas tramas ficcionais, problematizando a relação entre linguagem e justiça. Flaubert e Dostoievski, por exemplo, apresentam o personagem ressentido como o novo paradigma de protagonista. Eles passaram a, gradativamente, abandonar a representação de feitos heroicos e grandes obras, para enfocar em personagens simplórios, amiúde fracos e covardes, embora verbalmente articulados, capazes de (ab)usar das palavras em proveito próprio e em prejuízo de inocentes, deixando um rastro de violência e morte no caminho.

O protagonismo do ressentido sobrevive na Literatura até hoje, fornecendo um amplo material de estudos a respeito das relações entre a 
linguagem e o Direito, ou então, entre o (ab)uso das palavras e a violência institucionalizada. 0 que merece atenção são os motivos pelos quais o ressentimento entrou na cena literária, permanecendo mesmo no contexto do pós-guerra. Esses ficcionistas estavam detectando os sintomas de uma decadência cultural, a deterioração exponencial dos valores outrora constitutivos e mantenedores da sociedade. 0 esgarçamento do tecido social. Da Constituição. Dentro de poucas décadas, seus personagens fictícios ganhariam carne e osso, muitos deles se tornariam juristas, e usariam de suas habilidades verbais para violentar em massa as minorias (WEISBERG, 1984, p. 1-23).

Enquanto a Europa fora avisada por Flaubert e Dostoievsky, décadas antes das Grandes Guerras e dos campos de concentração, o Brasil também teve por profetas literários Machado de Assis, Graciliano Ramos, e Guimarães Rosa, observadores privilegiados da nossa realidade, que perceberam o desenvolvimento do constitucionalismo aliado a um modo de (re)produção social escravista, que serviria de óbice à efetiva separação dos poderes e garantia dos direitos fundamentais. Ao tematizar o ressentimento e a (in)justiça, eles também previram os estados de exceção da República Velha, do Estado Novo e da ditadura civil-militarempresarial de 1964-87. Seus romances são, no sentido goetheano, romances de formação do Brasil.

As raízes do ressentimento brasileiro, por sua vez, remontam à nossa "tradição paternalista e cordial de mando, que mantém os menos favorecidos em uma relação de dependência filial e servil em relação às autoridades políticas ou patronais" (KEHL, 2015, p. 323). A aparente docilidade do povo brasileiro, e seu hábito de esquecer traumas e ofensas históricos, nos leva a "rejeitar a memória e abandonar os projetos de reparação de injustiças passadas" (KEHL, 2015, p. 326). Por não passarmos nada a limpo, não elaborarmos nossos traumas e tampouco valorizarmos nossas conquistas, "nós, brasileiros, não nos reconhecemos no discurso que produzimos e sim naquele que o estrangeiro produz sobre nós" (KEHL, 2015, p. 327).

Assim, o tema da identidade nacional, objeto de discussão desde o surgimento dos Estados-nação modernos, influenciando inevitavelmente a compreensão da história do constitucionalismo como processo de 
aprendizado social (ROSENFELD, p. 2003), tem relação direta com o ressentimento. Nas palavras de José Carlos Reis (2006, p. 10), o problema da identidade interessa, sobretudo, aos fracassados, aos que "perdem sempre e ficam perdidos [...] talvez porque não saibam quem sejam, por não conseguirem ver o próprio rosto". Por não nos reconhecermos no espelho da cultura ocidental moderna, não definirmos o que desejamos e desconhecermos nossa própria capacidade de realização, nos encontramos internamente derrotados.

Afinal, é quase modismo, no Brasil, afirmar que nosso processo de constitucionalização, desde o início, configurou-se um processo fictício (ANDRADE, BONAVIDES, 1991), simbólico (NEVES, 1994), simulacro (STRECK, 1999), tardio (SILVA E NETO, 2016) ou fracassado (BARROSO; BARCELLOS, 2003). Seu fundamento elitista, antidemocrático, e sua trajetória marcada pela contradição estrutural entre constitucionalidade formal e material, por mais retrocessos que avanços na concretização da separação dos poderes estatais e da garantia aos direitos fundamentais, mais traumas que conquistas, mais descontinuidades que continuidades, na tradição democrática. Enfim, um processo de constitucionalização falso, de fachada ${ }^{4}$, comparado aos que ocorreram nos Estados Unidos, na França e na Alemanha, países centrais que exportaram e exportam suas teorias jurídicas para cá

Este sentido comum histórico ${ }^{5}$ endossado pela quase unanimidade dos juristas brasileiros, entretanto, revela o profundo rancor que cultivamos em relação ao nosso passado. Mutatis mutandis, o fenômeno que Harold Bloom (2014, p. 20 e seguintes) chamou de escola do ressentimento nos círculos literários, manifesta-se também no âmbito jurídico-político nacional. Podemos falar de uma escola do constitucionalismo ressentido no Brasil, que acaba por desembocar, na pior das hipóteses, em posturas imediatistas e/ou "de vanguarda" pelos Poderes ou Funções do Estado, relativizadoras dos preceitos constitucionais em prol de fatores contingenciais.

Os discípulos mais fiéis da escola do constitucionalismo ressentido se encontram entre os defensores de posturas messiânicas ou vanguardistas do Judiciário, que deve(ria) empurrar a história da civilização em direção ao "progresso" e higienizar a sociedade da corrupção. Para esta 
parcela de juristas e/ou intelectuais, a história de nosso processo de constitucionalização necessita ser "vingada", nem que seja à custa da própria Constituição vigente (o caso do julgamento do Habeas Corpus no 126.292/SP, pelo Supremo Tribunal Federal, é paradigmático). Não percebem que sua sede de vingança somente prolonga uma longa trajetória de desrespeito ao texto constitucional, o verdadeiro critério de legitimidade do Direito.

Aqui, mais uma vez, cabe destacar o papel da Literatura: ela "desenvolve em nós a quota de humanidade na medida em que nos torna mais compreensivos e abertos para a natureza, a sociedade, o semelhante" (CANDIDO, 2011, p. 182). Existe um potencial pedagógico e humanizador na Literatura. 0 estudante de Direito, graduado ou não, tem nas ficções um rico repositório da nossa tradição, da nossa cultura, que lhe permite ampliar seu horizonte de sentido e, assim, sua capacidade de se colocar no lugar dos outros.

\section{MACHADO DE ASSIS: DO CONSTITUCIONALISMO IMPERIAL AO REPUBLICANO}

0 primeiro ficcionista do ressentimento é Machado de Assis, quem viveu a transição do constitucionalismo monárquico ao republicano. Conforme enfatiza Faoro (1976, p. 59-60), o bruxo do Cosme Velho sabia que as instituições político-jurídicas da monarquia constitucional não funcionavam como deveriam, ao modo liberal: "eleições formando maiorias, as maiorias constituindo os ministérios". Mas a causa do mau funcionamento da máquina política não estaria na (tão criticada) existência do Poder Moderador, cuja presença, para Machado, servia de "bode expiatório a outras deficiências, mais visíveis e que todos sentem", e cujas origens remontam ao processo de formação do Estadonação. Os romances da fase madura de Machado de Assis, assim, se debruçam sobre essas deficiências de formação histórica que acometem a sociedade brasileira ${ }^{6}$.

Em Verba Testamentária, crônica presente em Papeis Avulsos (1880), começa-se a delinear o protótipo do protagonista ressentido na cena 
literária brasileira. A narrativa, semelhante às Memórias Póstumas de Brás Cubas, inicia-se com a morte do protagonista Nicolau, apresentando o último pedido de seu testamento: que seu caixão fosse feito por um dos piores marceneiros do Rio de Janeiro, sujeito que o defunto, embora não conhecesse, considerava "dos nossos melhores artistas, e um dos homens mais honrados da nossa terra". Passa-se então a explicar as causas da péssima escolha de Nicolau, convidando o leitor a "entrar em plena patologia" (ASSIS, 1944, p. 295-296). Machado, segundo John Gledson (2006, p. 77), apresenta-nos, nesta crônica, além do protótipo do protagonista ressentido, "uma interpretação satírica da história dos primeiros anos da independência" período marcado pelo fracasso na consolidação da estabilidade política, bem como por um "vaivém confuso entre as aspirações absolutistas e democráticas".

Nicolau leva a vida invejando doentiamente o caráter e a aparência dos outros membros da elite nacional, e descontando seu rancor nos escravos. Somente o sono e a bajulação dos subalternos amigos dão trégua à moléstia de Nicolau, quem é incapaz, inclusive, de adotar uma carreira profissional como diplomata ${ }^{7}$, por incapacidade de lidar com as figuras públicas e oficiais. Parlamentar constituinte sempre pontual, íntegro, desinteressado e patriota, o protagonista comemora intimamente o golpe de estado que dissolveu a assembleia, assim como a deportação de alguns dos constituintes - mas até o exílio se torna motivo de inveja: “Se ele também fosse exilado!" (ASSIS, 1944, p. 304-305). A inveja motiva também a participação de Nicolau nos movimentos revolucionários de 1831, tanto aos elogios quanto às críticas à figura do Imperador. A abdicação para ele torna-se um alívio, embora a regência lhe parecera insuportável, a ponto do protagonista se filiar ao partido conservador, restaurador ou regressista.

À semelhança do homem subterrâneo de Dostoievsky, quem não consegue lidar com as formas positivas de vida (beleza, poder, felicidade, bondade), Nicolau problematiza os modelos de vida que encontra, sem, entretanto, criar uma identidade própria; se, por um lado, os aceita (talvez em virtude da própria estrutura da sociedade brasileira, colonial e imitadora), por outro, "ele também rejeita violentamente esses modelos com impulsos semi-inconscientes, para ser independente 
e original", contudo, por não conseguir sê-lo, "só consegue continuar a viver procurando a companhia daqueles que lhe são manifestamente inferiores - com o resultado final de ser enterrado num caixão feito pelo pior carpinteiro do Rio de Janeiro" (GLEDSON, 2006, p. 76).

Pois o movimento de Independência brasileiro se apresentou ambíguo, contraditório, e ressentido como Nicolau. Rompeu com a dominação colonial, mas se deu contra uma revolução liberal portuguesa. Foi liberal, mas basicamente conservador, já que manteve o instituto da escravidão. Foi nacional, ma non troppo, já que a ideia de nação que prevaleceu foi montada pelos proprietários de escravos como forma de manter a dominação social e o poder político. Por fim, o processo revolucionário da Independência não tornou o Brasil propriamente independente, já que o país saiu de um antigo sistema de dependência jurídico, política e econômica (de Portugal) para outro, desta vez com a Inglaterra (NOVAIS; MOTA, 1996, p. 83). 0 processo de desenvolvimento físico e moral de Nicolau acompanha o processo de emancipação política e constitucionalização nacional, possibilitando ler Verba Testamentária como um conto de (de)formação histórica do país.

Outrossim, a constante da Constituição Imperial de 1824, e seu regime monárquico, mostra-se na "antinomia dos princípios liberais e absolutistas, gravados na Constituição outorgada; o Estado semiliberal e semi-autoritário, e escravista que tivemos" (BONAVIDES, 1969, p. 28). Liberal, monárquica e escravista, nossa primeira constituição reflete de forma cristalina, o compromisso inicial da sociedade brasileira, recémemancipada, entre ideias e instituições distintas e até antagônicas: de um lado, o absolutismo, representado na outorga da Constituição e na presença do Poder Moderador em seu texto e; de outro, o liberalismo, visto nos direitos civis e políticos e no sistema representativo inaugurado. Sob esta (aparente) antinomia, surge o verdadeiro compromisso fundador do Estado-nação brasileiro: o escravismo.

Por detrás da retórica constitucional e seus debates concentrados no Poder Moderador, odiado pelos críticos e justificado pelos adeptos do regime constitucional imperial, existia uma estrutura social escravista que, importando e distorcendo os princípios liberais informadores do constitucionalismo norte-americano e europeu, era a verdadeira 
responsável pela (de)formação do constitucionalismo tupiniquim (SALLES, 2013, p. 44-45).

Esta bizarra união entre liberalismo e escravismo no Brasil foi tema recorrente nas obras machadianas, não raro, representadas em seus romances, contos e crônicas pela alegoria da traição. Memórias Póstumas de Brás Cubas é o exemplo por excelência. Assim como em Verba Testamentária, a trajetória do protagonista Brás Cubas e os eventos que nela influíram, possuem inúmeros pontos de contato com os eventos que conformaram o desenvolvimento do constitucionalismo imperial brasileiro.

A traição em nível individual que surge na trama de Memórias Póstumas poderia corresponder, muito bem, à traição dos ideais liberais de todas as constituições modernas (pacto social) pela comunidade política e jurídica brasileira; ou, ainda, poderia corresponder à traição do recém-constituído Estado-nação brasileiro para com seu povo (constituído na sua maioria por escravos). Afinal, embora a Constituição do Império de 1824 tivesse prometido o fim das penas cruéis (art. 179, XIX), o Código Criminal do Império de 1830 as manteve para os escravos: a maioria da população nacional estava sujeita a receber até cinquenta açoites por dia (art. 60).

Brás Cubas, assim como Nicolau, é mais um herdeiro e senhor de escravos entre os muitos que permeiam a obra de Machado. Sua formação jurídica ${ }^{8}$ vem aliada a uma enorme propensão em elaborar teorias (como a das edições, a filosofia da ponta do nariz, a lei da equivalência das janelas, o humanitismo) que explicam e justificam os fracassos que ocorrem na sua trajetória de vida. 0 ressentimento de Brás Cubas, portanto, não é uma reação à perda do(s) objeto(s) pretendido(s), e sim reação à própria perda do poder, o que justifica sua relação com a impotência (REGINSTER, 2016, p. 59).

Merece atenção o fato de que Brás Cubas, desde pequeno, observa o exercício da violência por meio das palavras, sendo capaz em diversas vezes de se conscientizar quanto à retórica da dominação senhorial que lhe garante seus privilégios; mas é incapaz, entretanto, de perceber a intimidação e violência inerentes ao exercício de tais estruturas linguísticas, preferindo aliar-se a elas, reproduzindo-as (CHALHOUB, 2003, p. 61-64). E, assim 
como a filosofia da ponta do nariz de Cubas, o Humanitismo, parodiando as teses da struggle for life e da ordem e progresso contemporâneas ao lançamento do romance, é um (falso) elogio da sociedade brasileira, cujas características (hierarquizada e estática) contrastavam curiosamente com as das sociedades exportadoras daquelas ideias (competitivas e dinâmicas) (SCHWARZ, 2000, p. 164-165). 0 que nos leva a recordar mais um romance machadiano: Quincas Borba.

Dado que, no Brasil, conforme salienta Caio Prado Jr. (2004, p. 278), o trabalho escravo, seja no campo ou nas cidades, fora onipresente, tornando "muito restrito o terreno reservado ao trabalho livre", é cômico como os porta-vozes do Humanitismo, Quincas Borba, Brás Cubas, e também Rubião, embora nunca tenham lutado para conquistar ou manter sua fortuna, pregam a todo momento que as batatas pertencem aos mais fortes, habilidosos, capazes. Ao cabo, a filosofia de Borba justifica com ares ilustrados "a indiferença dos ricos pelo destino de seus dependentes, indiferença que à luz de orientações mais tradicionais pareceria indecorosa”, bem como explica "o caráter necessário e legítimo da exploração colonial e de suas sequelas presentes" (SCHWARZ, 2000, p. 166). Trata-se, portanto, de mais uma construção verbal antitética aos valores da justiça.

A identificação ilusória de Rubião com Napoleão III, que corresponde à ilusão do Império brasileiro em se tornar "democrático", prosseguirá na história do nosso fictício constitucionalismo, através da "confiança imitativa" da próxima constituição, de 1891, no modelo liberal norte-americano, bem como no bacharelismo de Rui Barbosa, os quais passaram longe de interferir na estrutura social brasileira, ou seja, "sem fazer sequer pequenos corretivos de ordem econômica e social e sem que a esfera dos mecanismos de representatividade funcionasse de forma legítima" conforme determinavam os princípios liberais em voga nos países modernos. A vontade popular expressa nas atas eleitorais, assim como no Império, configurar-se-á “[n]uma contrafação da soberania representativa, formulada em nascentes rurais, demonstrativas da hegemonia, força e prestígio dos coronéis" (ANDRADE, BONAVIDES, 1991, p. 7-8). 
O sistema político-jurídico brasileiro, nesse sentido, embora se transfigure paulatinamente no século XIX e inaugure o século XX com uma constituição republicana, não deixará de estar imerso na tradição paternalista e cordial de mando, legada pelo escravismo, responsável por manter "os subordinados em uma relação de dependência filial e servil em relação às autoridades políticas ou patronais, na expectativa de ver reconhecidos e premiados o bom comportamento e a docilidade de classe" (KEHL, 2015, p. 323). Impossível não associarmos essa afirmação de Kehl ao modo brutal como Rubião trata seu (em verdade) único e fiel amigo-cão, que afinal é o duplo do protagonista (e da nação).

O que se pode aprender com Machado de Assis é a olhar com ceticismo as mudanças ocorridas no Brasil da segunda metade do século XIX. A mera troca do aparelho político-jurídico monárquico pelo republicano não seria o bastante para nos tirar do "atraso" em relação aos países modernos. Tampouco a Abolição seria responsável pelo fim do modo de reprodução social escravista, na medida em que nenhuma política social foi feita no objetivo de reparar a desigualdade social produzida pelo regime servil. 0 pacto das elites dirigentes com 0 escravismo como modo de (re)produção social dominante, a verdadeira e perene constituição brasileira, continuaria em vigor, reproduzindo a tradição cordial de mando, cenário que apenas se alterará na primeira metade do século XX.

\section{ENTRE RAMOS E ROSA: DO ESTADO NOVO À DITADURA CIVIL-MILITAR-EMPRESARIAL}

As revoluções de 1930 e 1932, bem como a promulgação da Constituição Federal de 1934, constituem eventos de referência para o constitucionalismo social brasileiro. Como em Weimar antes da ascensão de Hitler, o que se presencia na sociedade brasileira é uma rica e profunda transformação na mentalidade política e artística nacional, insatisfeita com o liberalismo à moda no século anterior. Poucos anos depois, todavia, tanto a Alemanha quanto o Brasil entrariam em um longo período de exceção constitucional. Graciliano Ramos é um dos expoentes da nova 
mentalidade na Literatura brasileira pós-30, além de ter feito parte dos quadros do Estado.

Ao contrário de Machado, que mantinha entre seus personagens e protagonistas prediletos figuras urbanas, intelectuais e/ou juristas, Graciliano privilegia em suas ficções o sertão e seus habitantes, como meio de representar a situação marginal do Brasil em relação aos países centrais. $\mathrm{O}$ ambiente do sertão, ao encarnar as contradições sociais de um país ainda a meio caminho da modernização, acaba por representar a própria situação (periférica ou sertaneja) do Brasil frente aos princípios constitucionais das potências capitalistas centrais.

A maioria das ficções de Graciliano Ramos - com a exceção, talvez, de Vidas Secas (1938) - tem por tema as confissões de seus protagonistas ressentidos: com o passado, com o amor, com a vida. Solitários, introspectivos ${ }^{9}$, utilizam a escrita como ferramenta de busca não apenas do Outro, mas de si mesmos, busca cujo resultado é o estranhamento e o sentimento de ausência (SOARES, 2007, p. 9). Revoltados com as forças da modernidade, "uma força que os arrasta, impossibilitandoos de se relacionar como outro, privando-os da potência de amar [...] impossibilitando uma vida humana mais digna, quase utópica" (SOARES, 2007, p. 14, grifo nosso), os protagonistas de Graciliano nos dão as pistas do que acontecerá com a sociedade brasileira nos idos do século XX. São Bernardo, publicado no mesmo ano da primeira constituição social brasileira, 1934, é um exemplo digno de nota.

Os fatos narrados por Paulo Honório, o protagonista de S. Bernardo, se dão em Viçosa, interior de Alagoas, pouco antes da Revolução de 30. Dono de terras e coronel considerado em Viçosa, Paulo Honório resolve, para dar um herdeiro a São Bernardo, casar-se com Madalena, professora na cidade. Logo surgem divergências entre o casal. Paulo Honório se ressente da instrução de Madalena e passa a sentir ciúmes da esposa, enquanto ela se horroriza com a agressividade do marido. Sem saída e constantemente abusada psicologicamente, Madalena comete suicídio. A Revolução eclode e os empregados abandonam a fazenda. Paulo Honório, na propriedade em cacos, resolve escrever um romance sobre sua história.

A posse de São Bernardo, e de Madalena, diferem pouco na ótica do protagonista, que procede do mesmo modo - linear e pragmático - na 
sua conquista. Madalena, entretanto, recusa submeter-se ao processo de reificação que Paulo Honório impõe ao mundo ao seu redor, tornandose um obstáculo ao dínamo modernizador. Contra o que se ressente o protagonista de São Bernardo? A resposta, segundo Kehl (2015, p. 241-242), é: "Contra tudo o que, em Madalena, escapa de seu hábito de dominar". A bondade e a cultura de Madalena expõem a rudeza e a maldade de Paulo Honório. Além disso, Madalena representa um ideal político antagônico ao de Paulo Honório: o comunismo, que será o grande inimigo-pretexto para a instauração da ditadura varguista em 1937.

A partir daí, a narrativa do protagonista muda de foco para a destruição de Madalena, de São Bernardo e do próprio Paulo Honório, mas na vitória, afinal, da reificação típica da mentalidade capitalista. Eliminada fisicamente, Madalena representa a morte das ações do protagonista-narrador, incapaz até mesmo de organizar os trabalhos de seu projeto de romance autobiográfico. A impotência então toma conta do narrador-protagonista ${ }^{10}$. 0 outrora ativo Paulo Honório "abandona a ação e volta-se sobre si mesmo, buscando na memória de sua vida o ponto em que se desnorteou, 'numa errada'” (LAFETÁ, 1983, p. 213). As palavras finais da narrativa - "e vou ficar aqui, às escuras, até não sei que hora, até que, morto de fadiga, encoste a cabeça à mesa e descanse uns minutos" (RAMOS, 1955, p. 195) - mostram a "vitória da reificação e a derrota total do herói, que é incapaz de mexer-se, modificar-se" (LAFETÁ, 1983, p. 213).

Em S. Bernardo, o ressentido Paulo Honório é o símbolo do capitalista tupiniquim na década de 30. Em termos históricos, o protagonista re(a) presenta a modernização contraditória e autoritária do país no início do século passado, "aberta e funcional só para os que têm acesso à dominação burguesa" (FERNANDES, 1986, p. 274). Ocorre que a burguesia brasileira que emerge nos anos 30, como os protagonistas-narradores de Graciliano Ramos, não assume, a exemplo do ocorrido na Inglaterra, Estados Unidos e França, "o papel de paladina da civilização ou de instrumento da modernidade", preferindo, ao invés disso, "tirar proveito dos tempos desiguais e da heterogeneidade da sociedade brasileira, mobilizando as vantagens que decorriam tanto do 'atraso' quanto do 'adiantamento' das populações” (FERNANDES, 1986, p. 267). 
O horizonte de expectativas, pois, tanto da burguesia quanto da oligarquia nacional, quanto à revolução de 30 , era "essencialmente o mesmo, polarizado em torno de preocupações particularistas e de um entranhado conservantismo sociocultural e político" (FERNANDES, 1986, p. 272). São Bernardo, assim, antecipa uma característica fundamental do nosso processo de constitucionalização social: a incapacidade de diálogo democrático com as classes sociais menos favorecidas e o uso antissocial do aparato estatal, "em favor do privilégio e dos privilegiados [e] [...] contra a coletividade" (FERNANDES, 1992, p. 221). Assim como os protagonistas dessas narrativas, o Estado brasileiro de 30 em diante foi incapaz de dialogar com as demandas sociais, sufocando-as sob a mais violenta repressão.

No resto do mundo, os movimentos operários e associados da primeira metade do século XX tiveram importância política fundamental no combate à opressão social e na transformação da natureza dos direitos humanos, alargando seu campo de incidência para além do individualismo-liberal presente na Declaração Francesa e na Constituição norte-americana (HOBSBAWN, 2005, p. 434-437). No Brasil da década de 30 , tais movimentos fracassaram em todas as tentativas de participação ativa do operariado no conluio militar revolucionário de 30 , sendo sufocados pela política trabalhista e policial do Estado Novo. Ou seja, os novos donos do poder não tinham real interesse na transformação da sociedade brasileira (CARONE, 1991, p. 34-37), preferindo tratar a questão social com uma política paternalista e repressora. A pobreza, antes que uma questão social, era tida por óbice à constituição da nacionalidade brasileira; o trabalho, antes que um direito fundamental, era obrigação e meio de servir à pátria (RIBEIRO, 2001, p. 142-143).

Passado o terror estado-novista, o Brasil entraria em um interregno democrático (1945-1964), caracterizado pelos ideais do desenvolvimentismo, nacionalismo e populismo; uma nova constituição, de tons liberais e sociais, fora promulgada (1946); e parecia que os tempos de ditadura tinham ido para nunca mais voltar. Grande Sertão: Veredas (1956), de Guimarães Rosa, é publicado neste contexto de otimismo e aliança entre progresso econômico e social, além do respeito por uma constituição social-democrata. 
Menos de dez anos depois, entretanto, a comunidade jurídica, bem como outros setores conservadores e "liberais" da sociedade brasileira, colaborarão abertamente para a derrubada do regime constitucional e a instauração de uma ditadura militar que durará por mais de vinte anos (1964-1987), destruindo a separação dos poderes e o respeito aos direitos fundamentais, perseguindo, torturando, estuprando e assassinando os opositores do regime, enquanto justificava seus atos (ab)usando da retórica jurídica e dos "milagres econômicos".

Riobaldo, o narrador e protagonista do romance de Rosa, que passa de jagunço-guerreiro a fazendeiro-ascético por meio de um pacto realizado com o diabo, antecipa este comportamento paradigmático das culturas sob o signo do ressentimento: afinal, toda a narração de Riobaldo é nada menos que expiação textual/verbal pela morte de seu amigo e grande amor Diadorim, que morre lutando por ele contra Hermógenes. Outrossim, embora Grande Sertão Veredas remeta à República Velha, existem indícios de que esse romance seja - dentre os demais aqui trabalhados - o que mais se adéqua ao gênero de formação histórica do Brasil.

O protagonista-narrador de Grande Sertão não é um jagunço qualquer. Trata-se, como aponta Galvão (1972, p. 81), de um jagunçoletrado, alguém que tem "seu destino entre as armas e as letras". Por isso, ele é capaz de tomar uma posição crítica ante os discursos dos chefes, sobretudo Zé Bebelo, aprendiz e professor que lhe ensina a retórica do poder, bem como do modo de vida jagunço. Mas assim como Brás Cubas, Riobaldo dominará a retórica jurídica e a utilizará para fins pessoais e vingativos, causando morte e destruição por onde passa.

E é Diadorim - ou, talvez, o próprio Sertão - que, como muitas outras personagens femininas na Literatura do ressentimento, constitui a forma positiva de vida, a derradeira vítima do ódio do nosso protagonistanarrador, ao qual só resta expiar a culpa verbalmente. Diadorim, o Sertão e a coragem, outrora constantes na primeira parte da narrativa de Riobaldo, vão perdendo espaço aos poucos, enquanto se aguçam as questões sociais (simbolizadas pelo encontro com os catrumanos e pela visita ao povoado do Pubo) (BOLLE, 2004, p. 209-210); e o nosso jagunço-letrado vai se distanciando dos companheiros, aproximando-se dos latifundiários, preparando-se para assumir a chefia do bando. Para isso, Riobaldo vai 
paulatinamente abandonando Diadorim como modelo e adotando o exemplo do inimigo Hermógenes: realizar o pacto com o Diabo.

Por meio da metáfora jurídica do contrato, Riobaldo ascende, superficialmente, de secretário ou professor a chefe Urutú-Branco da jagunçagem; porém, em um nível mais profundo, de jagunço-letrado a latifundiário-ascético. Só que essa ascensão social de Riobaldo tem por contraprestação a queda ética do protagonista, além da perda de seu grande amor Diadorim. As contribuições analíticas de Bolle são, mais uma vez, de grande importância. Para ele, a alegoria jurídica mais importante do romance não é o julgamento de Zé Bebelo na Fazenda Sempre Verde, mas o contrato de Riobaldo com o Diabo.

A sequência de ações que se sucede após o pacto diabólico, quando o protagonista-narrador já tomou a chefia do bando de jagunços, revela "uma série de desmandos" (BOLLE, 2004, p. 178), acompanhados pelo olhar vigilante e íntegro de Diadorim, quem não compreende ou sequer reconhece mais Riobaldo (BOLLE, 2004, p. 258). 0 chefe Urutú-Branco espalha medo e morte por onde seu bando passa, aliciando a mão-deobra miserável quase à força e extorquindo dinheiro dos fazendeiros. Em termos histórico-político-sociais, o trato diabólico de Riobaldo constitui a alegoria da verdadeira (e oculta) lei fundadora do Brasil: o pacto passa a ser "a alegoria de uma ação legal fundadora, uma 'constituiçãoo"' (BOLLE, 2004, p. 335, grifo nosso).

Afinal, que tipo de (con)trato é esse? "Trato? Mas trato de iguais com iguais. Primeiro, eu era que dava a ordem". Na perspectiva de Bolle, inovadora em relação às demais interpretações de GSV, "o trato entre iguais em que uma das partes dá as ordens representa [....] a relação entre senhores e escravos", lei fundadora mais profunda que qualquer das constituições da história nacional (2004, p. 174). É um contrato social diabólico, antagônico ao discurso iluminista, embora com sua roupagem retórica.

A saudade que desencadeia a narração de Riobaldo, permeada pela retórica da culpa, que vai exponencialmente crescendo ao longo da narrativa, coloca Grande Sertão: Veredas, ao lado dos demais aqui expostos, como um romance de ressentimento e formação do Brasil. Apenas uma década após a publicação de GSV, o processo de 
modernização autoritária presente na República Velha e no Estado Novo será retomado no Brasil. 0 uso instrumental e bélico da racionalidade jurídica (LIMA, 2019), agora levada às últimas consequências, o desapego às camadas populares economicamente desfavorecidas, o abandono das decisões democráticas e, ainda, a necessidade legitimação via atos "milagrosos", tudo isso nos autoriza a defender que a chefia de Riobaldo antecipa, em dez anos, o que se sucederia na ditadura civil-militar-empresarial brasileira (1964-1986). Neste período politicamente convulsionado, a face do país mudou radicalmente, graças a (re)implantação de um processo de modernização conservadora, "embora tenha permanecido inalterada a posição hierárquica dos principais protagonistas sociopolíticos” (VIZENTINI, 2000, p. 14).

Como se sabe, o golpe civil-militar-empresarial de março de 1964, que (re)colocou o Brasil em estado de exceção, desta vez por vinte anos, foi concebido e sustentado discursivamente como uma revolução saneadora das instituições e necessária à democracia, que estaria deturpada, conforme a propaganda "liberal" da UDN, em um "mar de lama” (BASBAUM, 1976, p. 76), ou então, conforme a justificativa do AI-1, infectada pelo "bolsão comunista".

Certo é que a guerra contra Hermógenes fora um ótimo negócio para Riobaldo, que a utilizou como alavanca de ascensão social para a classe latifundiária, "dona do poder" político brasileiro, como vimos, desde antes da Independência nacional (BOLLE, 2004, p. 183). A revolução saneadora ainda se apresenta discursivamente "como uma grande mudança sem riscos de ruptura [...] a favor do capital" e passando ao largo da luta de classes: "o discurso se dirige, antes de mais nada, às classes médias, invocando valores tradicionalmente imputados a elas. Constituem elas o narratário do discurso" (FIORIN, 1988, p. 122, grifo nosso) - o mesmo perfil do fazendeiro-narrador Riobaldo, bem como de seu narratário.

O preço, entretanto, da "ascensão social" do Riobaldo-Tatarana, de exímio atirador e letrado-jagunço para o ascético latifundiário RiobaldoUrutú-Branco fora sua "queda ética", a eterna culpa da negligência pela vida de Diadorim, do futuro do Sertão, de pessoas inocentes, corajosas e, sobretudo, justas. É Diadorim quem faz justiça e mata Hermógenes, mas ela também é morta por ele. 0 nosso protagonista-narrador, enquanto 
dono do poder, assiste à cena - fraco e impotente, como todo protagonista ressentido - do alto de um sobrado, de uma casa-grande... 0 resto da vida de Riobaldo, também já vimos, resume-se em expiações verbais da culpa e fetichismos textuais, as duas idiossincrasias de todo jurista ressentido.

\section{CONCLUSÕES}

Este trabalho apresentou, por meio de um passeio panorâmico sobre textos literários de cânones nacionais, o contexto histórico, social, político e, sobretudo, cultural, das nossas seis constituições passadas. A Literatura, sobretudo quando não se tem certeza de nada, exsurge como privilegiado meio de compreender quem somos. Poderíamos compará-la ao barômetro, que mede a pressão da atmosfera de determinada região e indica prováveis mudanças no tempo. As ficções desta dissertação executaram com precisão esta função, no âmbito da cultura jurídica. Ao tematizar o ressentimento, elas foram o prenúncio de tempestades catastróficas para o nosso processo de constitucionalização, geradoras de descontinuidades em nossa tradição democrática.

Mas o ressentimento brasileiro está longe de ser um problema exclusivo dos juristas e intelectuais. Na verdade, sob uma perspectiva sociopolítica, o ressentimento traduz e sintetiza o volkgeist, o espírito do nosso tempo. A natureza reativa dos que compõem o governo eleito em 2018, seu ímpeto e vocação para gerar crises, seu discurso reacionário e antidiplomático, sua necessidade infindável de eleger, ou melhor, de forjar inimigos a serem combatidos a todo custo: seja o ambientalismo, seja a globalização, seja a ciência e a educação, seja a opinião pública, seja a cultura e as artes em geral, e, por fim, as instituições republicanas e democráticas, todos estes sintomas anunciam que a sociedade e o Estado estão sendo regidos por este veneno psicofisiológico típico dos fracos, impotentes e, no fundo, medrosos.

Falar de um constitucionalismo de ficções, nesse sentido, vai muito além de repetir a narrativa de um constitucionalismo fictício, simbólico, tardio, inefetivo, fracassado. Trata-se de salientar e apresentar à comunidade jurídica o potencial da Literatura para o estudo do 
processo de constitucionalização brasileiro, processo repleto de avanços e retrocessos, de continuidades e descontinuidades, e que tem nas ficções um poderoso repositório/laboratório/observatório da nossa tradição jurídico-política. As obras literárias aqui citadas constituem-se como narrativas de formação do Brasil.

A Literatura possui um poder premonitório. Ela não só possibilita estudos históricos, isto é, dirigidos à compreensão do nosso passado. As ficções podem prever catástrofes institucionais que abalaram a ordem jurídica constituída. A Literatura tanto nos informa a respeito do imaginário social de determinado contexto histórico, quanto pode nos dar indícios a respeito do futuro de determinada ordem jurídico-política situada no espaço-tempo, sobretudo quando na iminência de catástrofes institucionais. Enquanto incorporou os cânones europeus, também a literatura brasileira passou a tematizar o ressentimento e as relações entre linguagem e Direito, a seu modo. É uma relação que revela a ponte entre violência real e violência narrativa, entre ética e estética, entre forma literária e relação social, enquanto desvela a história do país.

\section{NOTAS}

1 Além da divisão trinária "clássica": Direito "na", "da" ou "como" Literatura, Ost ainda apresenta mais dois eixos pelos quais é possível pensar essa relação interdisciplinar: Direito "pela" Literatura, pelo qual se visam textos literários escritos por juristas ou políticos com o intuito de fazer avançar uma "causa"; e o eixo da Literatura "como" Direito, dos casos em que o texto literário é utilizado como fonte normativa pelas autoridades incumbidas de aplicar/interpretar o Direito (OST, 2017, p. 262).

2 "justiça é a boa vontade, entre homens de poder aproximadamente igual, de acomodar-se entre si, de 'entender-se' mediante um compromisso - e, com relação aos de menor poder, forçá-los a um compromisso entre si" (NIETZSCHE, 1998, p. 60).

3 "Historicamente considerado, o Direito representa [...] a luta contra os sentimentos reativos, a guerra que lhe fazem os poderes ativos e agressivos, que utilizam parte de sua força para conter os desregramentos do pathos reativo e impor um acordo. [...] o decisivo no que a autoridade suprema faz e impõe contra a vigência dos sentimentos de reação e rancor [...] é a instituição da lei, a declaração imperativa sobre o que a seus olhos é permitido, justo, e proibido, injusto: após a instituição da lei, ao tratar abusos e atos arbitrários de indivíduos ou grupos inteiros como ofensas à lei, como revoltas contra a autoridade mesma, ela desvia os sentimentos dos seus subordinados do dano imediato causado por tais ofensas, e assim consegue afinal o oposto do que deseja a vingança, a qual enxerga e faz valer somente o ponto de vista do prejudicado: daí em diante o olho é treinado para uma avaliação sempre mais impessoal do ato [...] Segue-se que 'justo' e 'injusto' existem apenas a partir da instituição da lei” (NIETZSCHE, 1998, p. 64-65).

4 Para uma crítica deste sentido comum histórico, consultar os estudos de Marcelo Andrade Cattoni de Oliveira (2010) e, ainda, de Rodrigo Francisco de Paula e Nelson Camatta Moreira (2016). 
5 Luis Alberto Warat (1994, p. 19) cunhou o termo sentido comum teórico dos juristas para designar os "métodos ilusórios, enobrecidas crenças, desapercebidos silêncios" que "envolvem as práticas interpretativas dos juristas de ofício. Teorias e práticas encarregadas de garantir a institucionalização da produção judicial da normatividade e seus efeitos de poder na comunidade. Práticas, mitos e teorias refinadas que se ligam estreitamente aos processos de produção heterônoma da ordem simbólica da sociedade". Adaptado ao campo dos estudos de história do Direito, podemos falar de um sentido comum histórico, isto é, um complexo de crenças a respeito do passado e expectativas de futuro no âmbito da prática jurídica.

6 Conforme o próprio Machado: “Não há dúvida que uma Literatura, sobretudo uma Literatura nascente, deve principalmente alimentar-se dos assuntos que lhe oferece a sua região [...] 0 que se deve exigir do escritor antes de tudo, é certo sentimento íntimo, que o torne homem do seu tempo e do seu país, ainda quando trate de assuntos remotos no tempo e no espaço" (CANDIDO, CASTELLO, 1968). Essa, inclusive, é a tese de Gledson (2003, p. 25): "Machado, como muitos outros romancistas do século XIX, desejava retratar a natureza e o desenvolvimento da sociedade em que vivia [...] suas intenções foram nesse sentido realistas".

7 Aconselhado pela irmã a adotar uma "carreira qualquer, alguma coisa em que se ocupasse", e pelo cunhado a seguir a diplomacia, o protagonista vai munido de uma carta de apresentação ao "ministro de estrangeiros", achando-o "rodeado de alguns oficiais da secretaria, prestes a ir ao paço, levar a notícia da segunda queda de Napoleão, notícia que chegara alguns minutos antes". Ante "as circunstâncias do momento" e as "reverências oficiais", Nicolau tem outro acesso de nervos, incapaz de encarar a "figura do ministro" - a ponto de ficar vesgo - e foge. Ao retornar à casa sentencia: "— Não quero ser nada! [...] fico com vocês e os meus amigos" (ASSIS, 1944, p. 301-303).

8 Aconselhado pela irmã a adotar uma "carreira qualquer, alguma coisa em que se ocupasse", e pelo cunhado a seguir a diplomacia, o protagonista vai munido de uma carta de apresentação ao "ministro de estrangeiros", achando-o "rodeado de alguns oficiais da secretaria, prestes a ir ao paço, levar a notícia da segunda queda de Napoleão, notícia que chegara alguns minutos antes". Ante "as circunstâncias do momento" e as "reverências oficiais", Nicolau tem outro acesso de nervos, incapaz de encarar a "figura do ministro" - a ponto de ficar vesgo - e foge. Ao retornar à casa sentencia: “- Não quero ser nada! [...] fico com vocês e os meus amigos” (ASSIS, 1944, p. 301-303).

9 “Não só o romancista está dominado por esse desejo de conhecer os seus semelhantes, mas esta aspiração é também dos seus personagens. Vivem todos voltados para dentro, com olhos que se inutilizaram quase para os quadros exteriores da vida" (LINS, 1995, p. 130-131).

10 "A verdadeira busca começa onde termina a vida de Paulo Honório. A busca verdadeira, entenda-se, a procura dos verdadeiros e autênticos valores que deveriam reger as relações entre os homens. A vida terminou, o romance começa. [...] Antes, Paulo Honório fora um personagem coeso e forte, movendo-se em um mundo de objetivos claros e (ainda que ilusório) repleto de significado: a propriedade. 0 suicídio de Madalena desmascara a falsidade do sentido e problematiza tudo. Agir para quê? - pergunta-se ele" (LAFETÁ, 1983, p. 210-212). 


\section{REFERÊNCIAS}

ADORNO, Sérgio. Os aprendizes do poder: o bacharelismo liberal na política brasileira. São Paulo: Paz e Terra, 1988.

ANDRADE, Paes de; BONAVIDES, Paulo. História constitucional do Brasil. 3. ed. São Paulo: Paz e Terra, 1991.

ASSIS, Machado de. Memórias Póstumas de Brás Cubas \& Quincas Borba. São Paulo: Círculo do Livro, 1989.

ASSIS, Machado de. Papeis avulsos. Rio de Janeiro: W. M. Jackson Inc., 1944, p. 295-296.

BARROSO, Luis Roberto; BARCELLOS, Ana Paula de. 0 começo da história. A nova interpretação constitucional e o papel dos princípios no Direito brasileiro. Revista de Direito administrativo, v. 232, p. 141-176, 2003.

BASBAUM, Leôncio. História sincera da República: de 1889 a 1930. 4 ed. São Paulo: Alfa-Omega, 1976. v. 2.

BLOOM, Harold. The western canon. Boston: Houghton Mifflin Harcourt, 2014.

BOLLE, Willi. Grande Sertão.br. São Paulo: Duas Cidades, 2004.

BONAVIDES, Paulo; ANDRADE, Paes de. História constitucional do Brasil. São Paulo: Paz e Terra, 1991.

BONAVIDES, Paulo. A crise política brasileira. Rio de Janeiro: Forense. 1969.

BRUNER, Jerome. Fabricando histórias: direito, literatura, vida. São Paulo: Letra e Voz, 2014.

CANDIDO, Antonio. 0 direito à literatura In: CANDIDO, Antonio. Vários escritos. 5. ed. Rio de Janeiro: Ouro sobre Azul, 2011.

CANDIDO, Antonio; CASTELlO, José Aderaldo. Presença da Literatura brasileira: Romantisno, realismo, parnasianismo, simbolismo. São Paulo: Difusão Europeia do Livro, 1968. v. 2. 
CARONE, Edgar. Brasil: anos de crise (1930-1945). São Paulo: Ática, 1991.

CHALHOUB, Sidney. Machado de Assis, historiador. São Paulo: Companhia das Letras, 2003.

COVER, Robert. Nomos e narração. Anamorphosis. Revista Internacional de Direito e Literatura, v. 2, n. 2, p. 187 268, 2016.

FAORO, Raymundo. Machado de Assis: a pirâmide e o trapézio. 2 ed. São Paulo: Nacional, 1976.

FERNANDES, Florestan. A concretização da revolução burguesa. In: IANNI, Octavio (Org.). Florestan Fernandes: sociologia crítica e militante. São Paulo: Ática. 1986.

FERNANDES, Florestan. Na revolução da democracia. In: BOSI, Alfredo (Org.). Cultura brasileira: temas e situações. 2. ed. São Paulo: Ática, 1992, p. 219-224.

FERRO, Marc. 0 ressentimento na história. Ensaio. Tradução de André Telles. Rio de Janeiro: Agir, 2009.

FIORIN, José Luiz. O regime de 1964: discurso e ideologia. São Paulo: Atual, 1988.

GALVÃo, Walnice Nogueira. As formas do falso: um estudo da ambiguidade no Grande Sertão: Veredas. São Paulo: Perspectiva. 1972.

GLEDSON, John. Por um novo Machado de Assis: ensaios. São Paulo: Companhia das Letras, 2006.

HÄBERLE, Peter. La Constitución como cultura. Anuario Iberoamericano de Justicia Constitucional, n. 6, p. 177-198, 2002.

HOBSBAWN, Eric. Mundos do trabalho: novos estudos sobre história operária. 4. ed. Trad. Waldea Barcellos. São Paulo: Paz e Terra, 2005.

KEHL, Maria Rita. Ressentimento. 4. ed. São Paulo: Casa do Psicólogo, 2015.

LAFETÁ, João Luiz. Posfácio. In: RAMOS, Graciliano. São Bernardo. 39 ed. Rio de Janeiro: Record, 1983, p. 189-213. 
LLANOS, Leonor Suárez. Literatura del derecho: entre la ciencia jurídica y la crítica literatura. Anamorphosis: Revista Internacional de Direito e Literatura, v. 3, n. 2, p. 349-386, 2017.

LIMA, Danilo Pereira. Legalidade e autoritarismo: o papel dos juristas na consolidação da ditadura militar de 1964. Salvador: Juspodvim. 2019.

LINS, Álvaro. Valores e misérias das Vidas Secas. Posfácio. In: RAMOS, Graciliano. Vidas secas. 69 ed. São Paulo: Record, 1995, p. 128-155.

NEVES, Marcelo. A constitucionalização simbólica. São Paulo: Acadêmica. 1994.

NIETZSCHE, Friedrich W. Genealogia da moral: uma polêmica. Trad. Paulo César de Souza. São Paulo: Companhia das Letras, 1998.

NOVAIS, Fernando A.; MOTA, Carlos G. A independência política do Brasil. 2. ed. São Paulo: Hucitec, 1996.

OLIVEIRA, Marcelo Andrade Cattoni de. Notas Programáticas para uma Nova História do Processo de Constitucionalização Brasileiro. Revista da Faculdade de Direito UFPR, v. 51, p. 45-72, 2010.

OST, François. Contar a lei: as fontes do imaginário jurídico. São Leopoldo: Unisinos, 2004.

OST, François. Direito e Literatura: os dois lados do espelho. Anamorphosis: Revista Internacional de Direito e Literatura, v. 3, n. 1, p. 259-274, 2017.

PAULA, Rodrigo Francisco de; MOREIRA, Nelson Camatta. 0 futuro passado do constitucionalismo brasileiro. Revista Eletrônica do Curso de Direito da UFSM, v. 11, n. 2, p. 734-750, 2016.

PRADO JR., Caio. Formação do Brasil contemporâneo: colônia. 23. ed. São Paulo: Brasiliense, 2004.

RAMOS, Graciliano. São Bernardo. 6. ed. Rio de Janeiro: Livraria José Olympio. 1955. 
REGINSTER, Bernard. Ressentimento, poder e valor. Cadernos Nietzsche, v. 37, n. 1, p. 44-70, 2016.

REIS, José Carlos. As identidades do Brasil: de Calmon a Bomfim: a favor do Brasil: direita ou esquerda? Rio de Janeiro: FGV, 2006. v. 2.

RIBEIRO, Luiz César de Queiroz. Cidade, nação e mercado: gênese e evolução da questão urbana no Brasil. In: SACHS, Ignacy, et. al. (Orgs.). Brasil: um século de transformações. São Paulo: Companhia das Letras, 2001, p. 132-160.

ROSENFELD, Michel. A identidade do sujeito constitucional. Trad. Menelick de Carvalho Neto. Belo Horizonte: Mandamentos, 2003.

SALLES, Ricardo. Nostalgia imperial: escravidão e formação da identidade nacional no Brasil do Segundo Reinado. 2. ed. Rio de Janeiro: Ponteio, 2013.

SCHWARZ, Roberto. Um mestre na periferia do capitalismo: Machado de Assis. São Paulo: Editora 34, 2000.

SILVA NETO, Manoel Jorge. 0 constitucionalismo brasileiro tardio. Brasília: ESMPU, 2016.

SOARES, Luis Eustaquio. Graciliano Ramos: um diálogo antimoderno com a modernidade. Espéculo: Revista de Estudios Literarios, n. 36, p. 58, 2007.

STRECK, Lenio Luiz. Hermenêutica jurídica e(m) crise: uma exploração hermenêutica da construção do Direito. Porto Alegre: Livraria do Advogado, 1999.

TRINDADE, André Karam; BERNSTS, Luísa Giuliani. O estudo do "direito e literatura" no Brasil: surgimento, evolução e expansão. Anamorphosis: Revista Internacional de Direito e Literatura, v. 3, n. 1, p. 225-257, 2017.

VESPAZIANI, Alberto. 0 poder da linguagem e as narrativas processuais. Anamorphosis: Revista Internacional de Direito e Literatura, v. 1, n. 1, p. 6984, 2015. 
VIZENTINI, Paulo G. Fagundes. O Brasil contemporâneo: autoritarismo e desenvolvimento (1961-1990). Ciências \& Letras: Revista da Faculdade PortoAlegrense de Educação, Ciências e Letras, n. 28, p. 13-42, jul./dez. 2000.

WARAT, Luis Alberto. Introdução geral ao Direito: interpretação da lei. Porto Alegre: Safe, 1994.v. 1.

WEISBERG, Richard $\mathrm{H}$. The failure of the word: The protagonist as lawyer in modern fiction. New Haven: Yale University Press, 1989.

Artigo recebido em: 31-8-2019

Aprovado em: 16-12-2019

\section{André Karam Trindade}

Mestre em Direito Público (UNISINOS) e Doutor em Teoria e Filosofia do Direito (Università Degli Studi Roma Tre/Itália). Coordenador do Programa de Pós-Graduação Stricto Sensu em Direito da UniFG, onde também coordena o SerTão - Núcleo Baiano de Direito e Literatura (DGP/CNPq). Professor Externo do Programa de Doctorado em Ciencias Jurídicas y Sociales da Universidad de Málaga (Espanha). Consultor Ad Hoc da Área do Direito da CAPES, FAPERGS e FAPESB. Membro da Comissão de Estudos Constitucionais da OAB/ RS. Sócio do Escritório Streck \& Trindade Advogados Associados. E-mail: andrekaramtrindade@gmail.com

\section{Guilherme Gonçalves Alcântara}

Mestre em Fundamentos e Efetividade do Direito pelo programa de pósgraduação stricto sensu do Centro Universitário Uni-FG. Professor de Direito Constitucional, Hermenêutica e Argumentação Jurídica, Direito Processual Civil Direito Civil, e Direito Internacional no Centro Universitário Uni-FG. Integrante do grupo de pesquisa Ser-Tão - Núcleo Baiano de Direito e Literatura e do grupo de pesquisa em Ética, autonomia e fundamentos do Direito. Ex-Bolsista CAPESPROSUP. Advogado. E-mail: guilhermealcantara@msn.com

Faculdade de Guanambi, Programa de Pós-Graduação em Direito.

Av. Pedro Felipe Duarte, 4911. São Sebastião. 46430000 - Guanambi, BA - Brasil 
